the faunas of the Portage and Chemung. Bulletins of American Paleontology, 2(6): 1-56.

Marks, E. 1952. The Helen Jeanne Plummer collections. The Micropaleontologist, 6(4):30-47.

MARKS, J. G. 1951. Miocene stratigraphy and paleontology of southwestern Ecuador. Bulletins of American Paleontology, 33(139):1-162.

MaUry, C. J. 1917. Santo Domingo type sections and fossils. Pt. I. Mollusca. Bulletins of American Paleontology, 5(29):65-415.

Olsson, A. A. 1922. The Miocene of northern Costa Rica with notes on its general stratigraphic relations; Mollusca. Pt. I, Class Gastropoda. Pt. 2, Class Pelecypoda. Bulletins of American Paleontology, 9(39): 174-340.

. 1928. Contributions to the Tertiary paleontology of northern Peru. Pt. I. Eocene Mollusca and Brachiopoda. Bulletins of American Paleontology, 14(52):47-200.

- 1929. Contributions to the Tertiary paleontology of northern Peru. Pt. 2. Upper Eocene Mollusca and Brachiopoda. Bulletins of American Paleontology, 15(57):67-116.

- 1930. Contributions to the Tertiary paleontology of northern Peru. Pt. 3. Eocene Molluscs. Bulletins of American Paleontology, 17(62):1-96.

- 1931. Contributions to the Tertiary paleontology of northern Peru. Pt. 4. The Peruvian Oligocene. Bulletins of American Paleontology, 17(63):97-260.

- 1932. Contributions to the Tertiary paleontology of northern Peru. Pt. 5. The Peruvian Miocene. Bulletins of American Paleontology, 19(68):1-272.
- 1934. Contributions to the paleontology of northern Peru. Pt. 6. The Cretaceous of the Amotape region. Bulletins of American Paleontology, 20(69):1-104.

- 1942. Tertiary and Quaternary fossils from the Burica Peninsula of Panama and Costa Rica. Bulletins of American Paleontology, 27(106): 153-258.

- 1944. Contributions to the paleontology of northern Peru. Pt. 7. The Cretaceous of the Paita region. Bulletins of American Paleontology, 28(111):159-304.

- 1967. Some Tertiary Mollusks from South Florida and the Caribbean. Paleontological Research Institution, Ithaca, New York, 62 p.

- AND R. E. PETrT. 1964. Some Neogene Mollusca from Florida and the Carolinas. Bulletins of American Paleontology, 47(217), $71 \mathrm{p}$.

PAlmer, D. K. 1945. Notes on the Foraminifera from Bowden, Jamaica. Bulletins of American Paleontology, 29(115), $82 \mathrm{p}$.

PAlmer, K. V. W. 1937. The Claibornian Scaphopoda, Gastropoda and dibranchiate Cephalopoda of the southeastern United States. Bulletins of American Paleontology, 7(32):1-730.

PALMER, R. H. 1948. List of Palmer Cuban fossil localities. Bulletins of American Paleontology, 31(128), $178 \mathrm{p}$.

WEISBORD, N. E. 1962. Late Cenozoic Gastropoda from Northern Venezuela. Bulletins of American Paleontology, 42(193), 672 p.

- 1964. Late Cenozoic pelecypods from northern Venezuela. Bulletins of American Paleontology, 45(204), 523 p.

ACCEPTED 15 JANUARY 1994

\title{
ANNOUNCEMENT
}

\section{ADDRESS FOR SUBMISSION OF MANUSCRIPTS}

Beginning in November 1994, manuscripts submitted for publication in the Journal of Paleontology are to be sent to the following address:

Dr. Daniel B. Blake

Managing Editor, Journal of Paleontology

Department of Geology

University of Illinois

1301 West Green Street, Room 245

Urbana, IL 61801 